\title{
CUS1, a suppressor of cold-sensitive U2 snRNA mutations, is a novel yeast splicing factor homologous to human SAP 145
}

\author{
Sandra E. Wells, Megan Neville, Michelle Haynes, Jianhua Wang, Haller Igel, and Manuel Ares Jr. \\ Biology Department, Sinsheimer Laboratories, University of California, Santa Cruz, Santa Cruz, California, 95064 USA
}

\begin{abstract}
The function of U2 snRNA in splicing is mediated by the proteins of the U2 small nuclear ribonucleoprotein. To identify proteins that influence the function of U2 snRNA we carried out a screen for mutations in Saccharomyces cerevisiae that suppress the cold-sensitive growth defect of a mutation in U2 stem loop IIa, a structure important for the stable association of the U2 snRNP with pre-mRNA. The screen identified three dominant suppressor genes, one of which, CUS1-54, encodes an essential splicing protein required for U2 snRNP addition to the spliceosome. The suppressor protein rescues the spliceosome assembly defect of the mutant $\mathrm{U} 2$ in vitro, indicating that suppression is direct. Allele specificity tests show that the suppressor does not simply bypass the requirement for U2 stem loop IIa. Extra copies of wild-type CUS1, but not CUS1-54, suppress the temperature-sensitive prp11 and prp5 mutations, linking CUS1 protein to a subset of other factors required at the same step of spliceosome assembly. CUS1 is homologous to SAP 145, a component of the mammalian U2 snRNP that interacts with pre-mRNA. The yeast genome also encodes a homolog of human SAP 49, a protein that interacts strongly with both SAP 145 and pre-mRNA, underscoring the conservation of $\mathrm{U} 2$ snRNP proteins that function in spliceosome assembly.
\end{abstract}

[Key Words: U2 snRNA; Saccharomyces cerevisiae; spliceosome assembly; pre-mRNA]

Received August 25, 1995; revised version accepted October 24, 1995.

The spliceosome is the large ribonucleoprotein particle responsible for removal of introns from nuclear premRNA transcripts. Spliceosome assembly and function are complex and dynamic, involving multiple transient protein-protein, protein-RNA and RNA-RNA interactions. The spliceosome is built on an intron-containing transcript by the sequential recognition of conserved sequence elements near the reactive sites. A transcript first becomes committed to the splicing pathway by stable association with the U1 small nuclear ribonucleoprotein (snRNP) to form the commitment complex, a step that does not require ATP. Stable binding of U2 snRNP to the commitment complex near the pre-mRNA branchpoint requires ATP and forms the prespliceosome. With the binding of U5/U4.U6 tri-snRNP the spliceosome is assembled but must be activated before the cleavage and ligation reactions begin (for review, see Moore et al. 1993; Newman 1994; Nilsen 1994; Ares and Weiser 1995).

The recognition of an intron and choice of splice sites are likely accomplished during the early steps of spliceosome assembly and may hold the key to the regulation of splicing. As the first ATP-requiring step, the stable addition of the U2 snRNP at the branchpoint is an attractive potential site of regulation. The RNA moiety of the U2 snRNP plays two roles in this step. A region called the branchpoint interaction sequence forms base pairs with the pre-mRNA at the site of lariat formation (Parker et al. 1987; Wu and Manley 1989; Zhuang and Weiner 1989|. A structure downstream of the branchpoint interaction sequence called stem-loop IIa is an essential U2 structural element required for the stable binding of U2 snRNP to the assembling spliceosome in yeast (Ares and Igel 1990; Zavanelli and Ares 1991). Mutations that destabilize the stem are cold-sensitive for growth and splicing in vivo and in vitro (Ares and Igel 1990; Zavanelli and Ares 1991) and can be suppressed by second mutations in $\mathrm{U} 2$ that improve the stability of stem IIa or destabilize competing alternative structures (Zavanelli et al. 1994). A search for genetic interactions between $\mathrm{U} 2$ and known splicing proteins identified four proteins that function together with stem-loop IIa of U2: PRP5, PRP9, PRP11, and PRP21 (Ruby et al. 1993; Wells and Ares 1994). Each of these four proteins is independently required for prespliceosome assembly (Lin et al. 1987; Arenas and Abelson 1993; Ruby et al. 1993). Genetic interactions indicate that the four function closely with one another (Chapon and Legrain 1992; Ruby et al. 1993) and PRP21 interacts in the two-hybrid system with both PRP9 and PRP11 (Legrain and Chapon 1993; Legrain et al. 1993).

In mammals two multisubunit splicing factors designated SF3a and SF3b (Brosi et al. 1993b) are components of the U2 snRNP and are required for spliceosome as- 
sembly. Similarities between the three yeast U2 snRNPassociated proteins PRP9, PRP11, and PRP21 and components of SF3a indicate that SF3a structure and function are conserved between yeast and mammals (Beggs 1993; Behrens et al. 1993b; Krämer 1993; Hodges and Beggs 1994; Newman 1994). SF3a ${ }^{66} / \mathrm{SAP} 62$ (spliceosome-associated protein 62 ) is related to PRP11 by sequence similarity and immunological cross-reactivity (Bennett and Reed 1993). SF3a ${ }^{60} /$ SAP 61 is related to PRP9 by sequence similarity, immunological cross-reactivity, and functional domain exchange (Behrens et al. 1993a; Bennett and Reed 1993; Brosi et al. 1993a; Chiara et al. 1994; Krämer et al. 1994). SF3a ${ }^{120} /$ SAP 114 is related to PRP21 by sequence similarity (Krämer et al. 1995). Protein-protein interactions detected among PRP9, PRP11, and PRP21 (Legrain and Chapon 1993; Legrain et al. 1993/ are similar to those observed among the SF3a subunits (Bennett and Reed 1993; Chiara et al. 1994; Kr̈amer et al. 1995). Despite the similarity in SF3a from yeast and mammals, there has been no evidence for a yeast homolog of SF3b.

To identify factors that influence the function of $U 2$ RNA, we carried out a screen for mutations that suppress the cold-sensitive growth defect of the U2 G53A mutation in stem-loop IIa, a structure known to be essential for U2 function (Ares and Igel 1990). The screen yielded three different cold-sensitive $\underline{\mathrm{U}} 2$ suppressor genes, CUS1, CUS2, and CUS3. One of these, CUS1, encodes an essential splicing protein that is required for U2 snRNP addition to the spliceosome. The CUS1-54 suppressor rescues the cold-sensitive defect of U2 RNA at the step of stable U2 snRNP binding to pre-mRNA, indicating that rescue involves a direct rather than a bypass mechanism. The spectrum of U2 alleles suppressed by CUS1-54 indicates that stem-loop IIa of U2 RNA is an important target of the suppressor activity. Wild-type CUS1, but not the CUS1-54 mutant, mediates extra copy suppression of temperature-sensitive $\operatorname{Prp} 11$ and Prp5 mutations, linking the CUS1 protein to a subset of other factors required at the same step of spliceosome assembly. As described here and in Gozani et al. (this issue), CUS1 shares a large region of homology with SAP 145 , a protein component of the mammalian U2 snRNP (Staknis and Reed 1994). The yeast genome also encodes a homolog of SAP 49, a human protein that interacts with SAP 145 (Champion-Arnaud and Reed 1994; Gozani et al., this issue), demonstrating that key elements of SF3b are conserved in structure and function.

\section{Results}

\section{Genetic analysis of the CUS genes}

To identify mutations that increase the function of $\mathrm{U} 2$ snRNA, we carried out a genetic screen for suppressors of the cold-sensitive U2 mutation G53A (Ares and Igel 1990). Yeast cells carrying a U2 gene disruption in the chromosome and the cold-sensitive U2 snRNA gene on a LYS2 plasmid were treated with ethyl methanesulfonate (EMS) and cold-resistant colonies were isolated. Of $\sim 1.4 \times 10^{5}$ viable colonies screened, 105 were cold resistant. Each colony was crossed to a wild-type strain carrying a $\mathrm{U} 2$ disruption and a new copy of the cold-sensitive U2 gene on a LEU2 plasmid. The cold-sensitive growth phenotype of the resulting diploids was examined, and all were found to be cold resistant, indicating that they contain dominant or codominant suppressors. The diploids were then streaked on $\alpha$-aminoadipate to select for the loss of the LYS2 plasmid carrying the original U2 gene present during exposure of the cell to mutagen. Diploids that became cold sensitive upon loss of the LYS2 plasmid were shown to contain revertants of the original cold-sensitive U2 mutation or second-site U2 mutations that suppress the RNA folding defect of the original mutation (Zavanelli et al. 1994). Diploids that remained cold resistant were judged to contain dominant extragenic suppressors. Of the 36 strains in this class, the 16 strains containing the strongest suppressors were analyzed in detail. All were backcrossed to wild type at least twice, and the suppressor in each case segregated as a single Mendelian gene. None of the suppressor mutations carried a severe growth defect in combination with wild-type U2. We called these the CUS genes.

The suppressors were sorted into gene groups by linkage analysis, rather than by complementation, because they are dominant and lack obvious recessive growth defects. Pairs of strains containing independently isolated suppressors were crossed to each other, the resulting diploids were dissected, and spores were tested for cold resistance. In the case where the two suppressor mutations are in the same gene (tightly linked), very few if any cold-sensitive spores will emerge from the cross. If the suppressor mutations are in different genes (likely to be unlinked), most tetrads (the abundant tetratype class) will contain one cold-sensitive spore (Sherman and Wakem 1991|. We used these distinct patterns to determine that 12 isolates were in the same gene (CUS1), 3 isolates were unlinked to CUS1 but tightly linked to each other at a second locus (CUS2), and 1 isolate was unlinked to either of the first two mutations (CUS3). The 12 CUS1 isolates represent at least six independent events based on their appearance in different mutagenesis experiments. All three of the CUS2 mutations were isolated independently. The growth phenotypes of CUS $^{+}$, CUS1-54, CUS2-9, and CUS3-10 in combination with wild-type U2 or the cold-sensitive U2 G53A mutation are shown in Figure 1.

\section{Isolation of CUS1 and identification of the suppressor mutation}

To clone the CUS1 gene, a genomic library was constructed using a LEU2 centromere plasmid and DNA from a CUS1-54 strain carrying a cold-sensitive U2 gene. The library was introduced into a leu2 ${ }^{-}, \mathrm{CUS}^{+}$yeast strain carrying a U2 disruption and the cold-sensitive U2 gene on a LYS2 plasmid. Transformants that grew at $18^{\circ} \mathrm{C}$ on medium lacking leucine were isolated, and the LEU2 library plasmid was recovered from each and re- 
Wells et al.

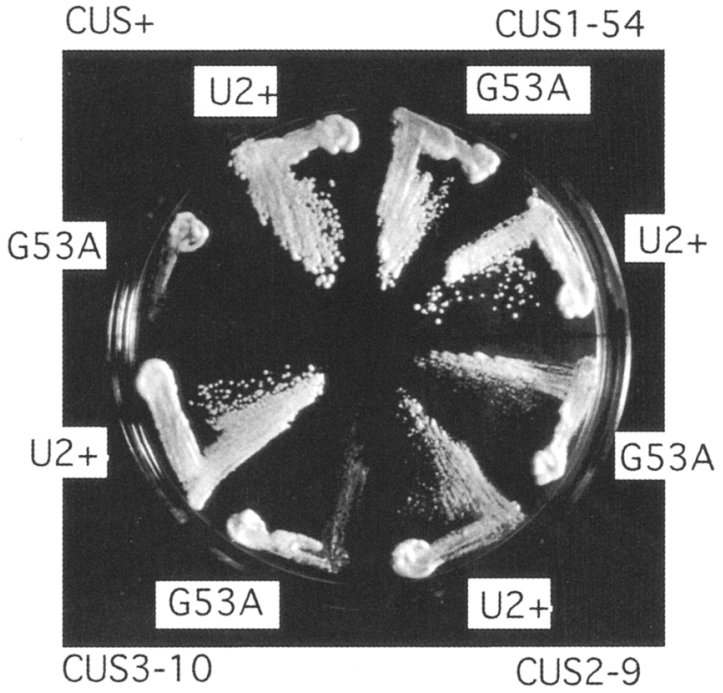

Figure 1. Suppression of cold-sensitive growth in mutagenized strains. Growth phenotypes of CUS ${ }^{+}$, CUS1-54, CUS2-9, and CUS3-10 in combination with wild-type U2 or the cold-sensitive U2 G53A mutation. Strains were streaked on YEPD and incubated for 4 days at $18^{\circ} \mathrm{C}$.

transformed into the original recipient strain. Three plasmids that uniformly suppressed the cold-sensitive growth phenotype upon retransformation were analyzed by restriction endonuclease digestion and were found to contain overlapping regions of the yeast genome. A subcloned 2055 base pair Xhol-HindIII fragment suppressed cold sensitivity and was sequenced, revealing an open reading frame that predicts a basic protein of 436 amino acids (Fig. 2; GenBank accession no. U27016).

To confirm that the cloned locus represents the CUS154 suppressor gene, we tested for genetic linkage be- tween CUS1-54 and the cloned sequences using strains carrying the cold-sensitive U2 mutation. A genomic fragment from downstream of the cloned gene was placed in an integrative vector carrying the $L E U 2$ marker and was used to target the insertion of the LEU2 gene into the chromosome next to the endogenous wild-type copy of the cloned gene, without disrupting it, thus creating a $\mathrm{Cus}^{+}$(cold sensitive), Leu ${ }^{+}$strain with LEU2 tightly linked to $C U S 1^{+}$. This strain was crossed to a leu2 ${ }^{-}$ CUS1-54 (suppressed cold-resistant) strain. We dissected 15 tetrads, all of which were parental ditypes (two coldsensitive, $\mathrm{Leu}^{+}$spores and two cold-resistant, Leu ${ }^{-}$ spores), indicating that recombination between the LEU2 marker integrated at the cloned locus and the CUS1-54 mutation did not occur. We conclude that the cloned genomic fragment is identical to the CUS1-54 suppressor.

Because we cloned and sequenced the mutant suppressor gene, we were unsure of the nature of the suppressor mutation. After we completed the suppressor sequence, a file containing the sequence of yeast chromosome XIII cosmid 9408 was deposited in the data base (GenBank accession no. Z48756). The two sequences matched at every position except one (1042 in Fig. 2), which predicted the replacement of the glutamic acid at position 181 with lysine within the CUS1-54 coding region (Fig. 2 ). To prove that this difference represents the suppressor mutation, we analyzed cloned CUS1 PCR products derived from the DNA of our wild-type strain and found $\mathrm{G}$ at position 1042. We created a clone of the wild-type allele CUS1 ${ }^{+}$by replacing A1042 of the CUS1-54 allele with $G$ using site-directed mutagenesis. As demonstrated below, the wild-type gene carried on a centromere plasmid does not suppress cold sensitivity. We conclude that alteration of the wild-type CUS1 ${ }^{+}$gene to the CUS1-54 suppressor of U2 cold sensitivity occurs by replacement of glutamate 181 by lysine. Analysis of PCR
Figure 2. The sequence of the 1934-bp XhoI-SacI fragment containing the CUS1 coding region. Predicted amino acid sequence of CUS1 is shown below the nucleotide sequence. Nucleotide and amino acid (in italics) positions are indicated at right. The positions of the mutation in the gene and the predicted amino acid substitution in the protein are underlined. In wild-type CUS1, position 1042 is a G and results in a glutamate at amino acid position 181 ; in the suppressor gene CUS1-54 there is an A at 1042 resulting in a lysine.

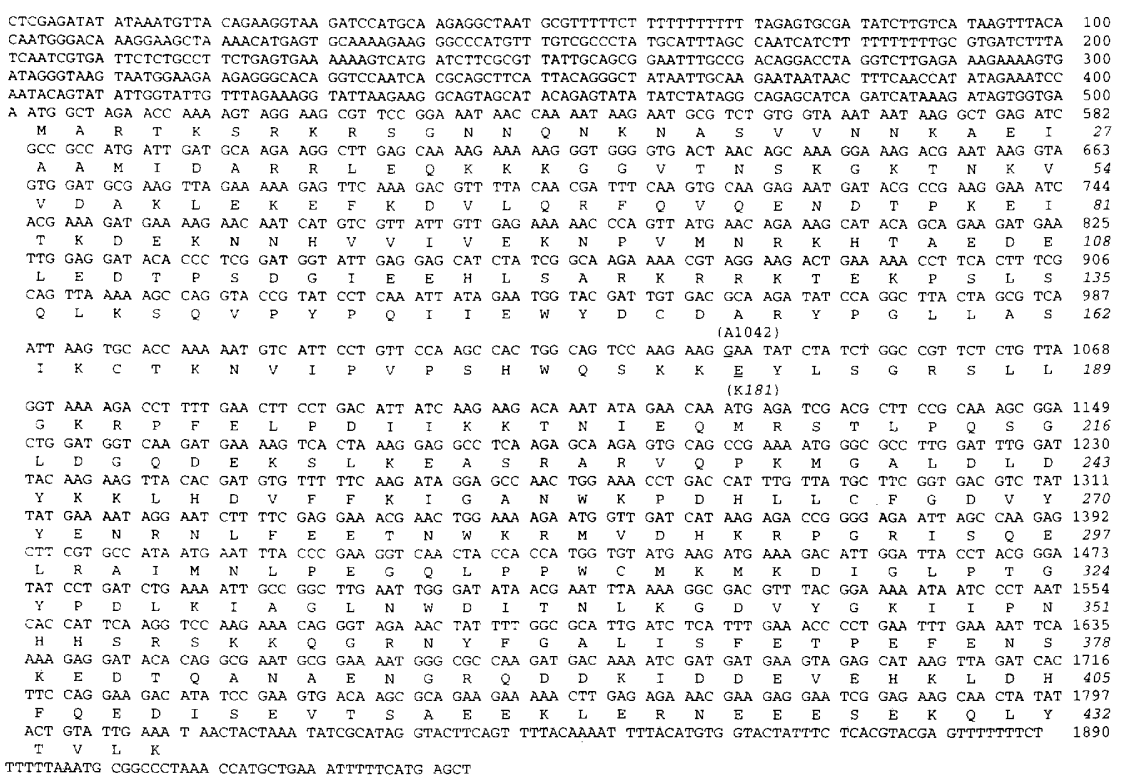


products derived from each of the remaining 11 CUS1 suppressor isolates shows that they all carry the same G1042 to A mutation.

\section{CUS1 is an essential splicing factor required for prespliceosome formation}

The genetic interaction between CUS1-54 and mutant U2 snRNA suggested that the product of the wild-type CUS1 gene might be a splicing factor. To determine whether CUS1 is an essential gene and to begin studying the role of the CUS1 gene product in splicing, we deleted a large segment of the CUS1 coding region and replaced it with the selectable HIS3 gene. This deletion construct was used to replace one of the CUS $1^{+}$alleles in a diploid yeast strain by one-step gene disruption (Rothstein 1991). Southern analysis confirmed that correct replacement occurred, and dissection of tetrads obtained by sporulating the diploid produced 2:0 segregation of viable spores, none of which was His ${ }^{+}$, indicating that disruption of CUS1 is lethal. The cus1::HIS3 null allele can be complemented by either the wild-type $C U S 1^{+}$gene or the CUS1-54 suppressor gene.

To determine whether CUS1 is required for splicing, we constructed a GAL1:CUS1 fusion and integrated it at the chromosomal locus of CUS1, such that the endogenous gene was deleted and replaced with a $G A L$-regulated copy of CUS1. To examine the effect of CUS1 protein depletion on splicing, we shifted strains carrying the GAL-regulated CUS1 gene to media containing glucose, isolated RNA, and measured changes in splicing and snRNA levels. Upon repression of the integrated, $G A L$-regulated CUS1 gene, growth is blocked and unspliced U3 RNA accumulates, indicating that loss of CUS1 gene expression inhibits splicing (Fig. 3A). In addition, a slight, reproducible increase in the level of U2 snRNA relative to $\mathrm{U} 1, \mathrm{U} 4, \mathrm{U} 5$, and $\mathrm{U} 6$ snRNAs is also observed (data not shown). We conclude that the CUS1 gene product is required for efficient splicing in vivo but is not required to maintain wild-type U2 RNA stability.

To determine the step in splicing at which the CUS1 gene product is first required, we prepared splicing extracts depleted of CUS1 from cells carrying the GAL1:CUS1 fusion shifted to glucose (Fig. 3B). When pre-mRNA is added to extracts depleted of CUS1 there is an accumulation of commitment complexes compared to a wild-type extract (cf. CC in lanes 1 and 2) but a dramatic decrease in the U2 snRNP containing prespliceosome and spliceosome complexes (cf. PS and SP in lanes 1 and 2). This indicates a requirement for CUS1 following commitment complex formation and prior to U2 snRNP addition. To provide evidence that the deficiency in the extract is attributable to loss of CUS1 we created a GAL1:CUS1 gene with a double tag (Peterson et al. 1994) composed of the hemagglutinin (HA) epitope (Kolodziej and Young 1991) followed by six histidines (Hochuli 1990) at the carboxyl terminus of the CUS1 protein (CUS1-tag). The tagged gene complements the cus $1:$ HIS 3 disruption (on galactose), indicating that the tag does not block the function of the protein /data not
A

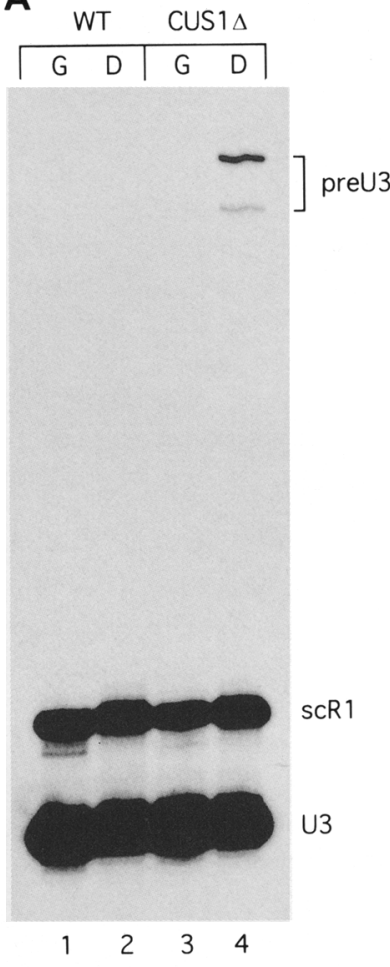

B

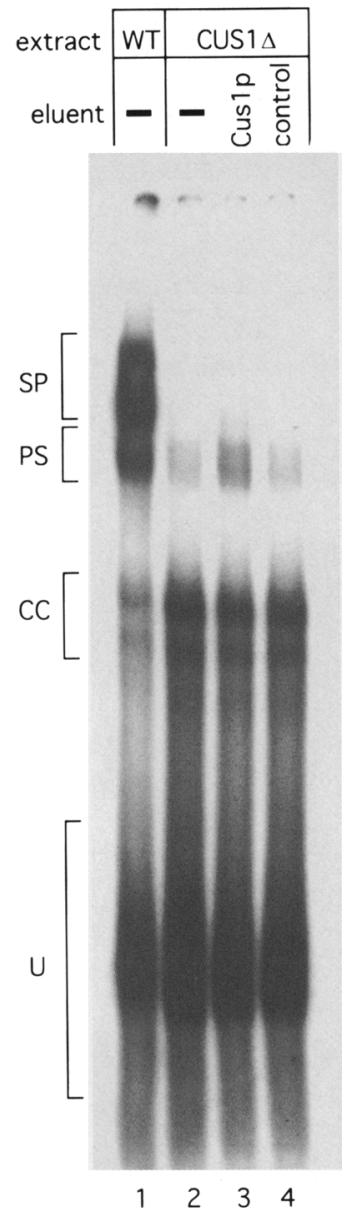

Figure 3. CUSl is an essential splicing factor required for prespliceosome formation. (A) Depletion of CUS1 results in accumulation of unspliced RNA. Total RNA was isolated from a strain carrying a glucose-repressible chromosomal CUS1 gene, SWY2, (lanes 3,4) or from an isogenic control strain, HI227, (lanes 1,2 ) following $7 \mathrm{hr}$ of logarithmic growth at $30^{\circ} \mathrm{C}$ in media containing either glucose $(D$, lanes 2,4$)$ or galactose $(G$, lanes 1,3 . The levels of spliced and unspliced U3 were measured by primer extension using an oligonucleotide complementary to the second exon of the U3A and U3B genes. An oligonucleotide complementary to scR 1 , a cytoplasmic RNA not involved in splicing (Felici et al. 1989), was included in each reaction as an internal control for RNA amounts. Samples are HI227 in YPGal (lane 1), HI227 in YEPD (lane 2), SWY2 in YPGal (lane 3), and SWY2 in YEPD (lane 4). (B) Splicing complex formation in extracts depleted of CUS1. Splicing extract from cells genetically depleted of CUS1 (CUS1D) was incubated with labeled actin pre-mRNA and complexes were analyzed on nondenaturing polyacrylamide-agarose gels. Nickel column eluents from yeast strains expressing tagged CUS1 (lane 3) or a control eluent (lane 4) were added to depleted extracts to test their ability to reconstitute splicing complexes. Samples are as follows: Wild-type extract (lane 1); CUS1-depleted extract (lane 2); CUS1-depleted extract plus tagged CUS1 eluent (lane 3), CUS1-depleted extract plus control eluent (lane 4). The complexes are indicated by brackets as follows: Nonspecific complexes (U); commitment complexes (CC); prespliceosomes (PS); and splicesomes (SP). 
shown). Using nickel chelate chromatography (Hochuli 1990), we isolated protein from cells expressing CUS1tag and tested its ability to restore prespliceosome formation in the CUS1 depleted extract (Fig. 3B, lanes 3,4). Buffer alone (lane 2) or the eluent from the untagged extract (lane 4) did not stimulate prespliceosome formation, whereas the eluent derived from cells expressing CUS1-tag (lane 3) reproducibly stimulated the formation of prespliceosomes. The magnitude of the reconstitution is only about twofold, but stimulation of prespliceosome formation is never observed with fractions prepared from untagged extracts (cf. lanes 3 and 4). There could be several explanations for the inefficiency of reconstitution. First, although we can easily detect the tagged protein on blots after denaturation, both immunoprecipitation and nickel chelate affinity purification of the native protein are inefficient, suggesting that the epitope tag is not readily accessible in the native protein. Second, the effect of genetic depletion of CUS1 on the levels of other gene products is unknown. Proteins or RNAs that may require interaction with CUS1 for their stability or appearance in the extract may be reduced, and thus even purified CUS1 may be inadequate to reconstitute completely. The extracts are prepared under native conditions; thus it is possible that the reconstituting activity depends on the recovery of CUS1-tag as part of a complex with other proteins. Numerous proteins can be detected in these fractions by silver staining SDS gels /data not shown). Nonetheless, the accumulation of commitment complexes in CUS1-depleted extracts and the re-

Figure 4. Suppression of cold-sensitive splicing and spliceosome assembly. $(A)$ The in vivo splicing defect of G53A is suppressed by CUS1-54. RNA isolated from strains expressing only wild-type or G53A $\mathrm{U} 2$ at $18^{\circ} \mathrm{C}$ in combination with CUS1 or CUS1-54 was subjected to primer extension analysis using a primer that recognizes both spliced and unspliced forms of U3. A U5 primer was included as an internal control. Primer extension products were quantified using a Molecular Dynamics PhosphorImager, and the ratio of preU3A to U3 was calculated. The value of this ratio for wild type was set at 1.0, and the values of the remaining ratios were determined relative to the wild-type value. $(B)$ Cold-sensitive spliceosome assembly is suppressed by CUS1-54. Splicing extracts carrying only wild-type or G53A U2 in combination with either CUS1 or CUS1-54 were incubated with radiolabeled actin pre-mRNA under splicing conditions at $15^{\circ} \mathrm{C}$ or $23^{\circ} \mathrm{C}$. Aliquots of $5 \mu \mathrm{l}$ were removed to quench at the times indicated and analyzed on a nondenaturing polyacrylamide-agarose gel. The complexes are indicated by brackets as follows: Nonspecific complexes $(\mathrm{U})$; commitment complexes (CC); prespliceosomes (PS); and splicesomes (SP). constitution of prespliceosomes by partially purified CUS1 demonstrates that CUS1 is required for U2 snRNP binding to pre-mRNA during spliceosome assembly.

\section{CUS1-54 suppresses U2 splicing defects in vivo and in vitro}

To investigate the mechanism by which the CUS1-54 protein suppresses the cold-sensitive growth defect of the U2 G53A mutation, we compared splicing efficiency at $18^{\circ} \mathrm{C}$ in isogenic strains expressing either the wildtype or mutant $\mathrm{U} 2$ and carrying a plasmid with either the wild-type CUS $1^{+}$gene or the CUS1-54 gene, in addition to a chromosomal copy of CUS1 ${ }^{+}$. RNA was isolated from each of four strains and subjected to primer extension analysis using a U3 oligonucleotide to detect unspliced pre-U3A and pre-U3B (Fig. 4A). Mutation of U2 G53A causes accumulation of unspliced U3 after a shift to $18^{\circ} \mathrm{C}$ (Zavanelli and Ares 1991; Fig. 4A, cf. lanes 1 and 3). Presence of the CUS1-54 plasmid almost completely suppresses the splicing defect caused by the U2 G53A mutation (cf. lane 4 with lanes 3 and 1) and causes no splicing defect in cells expressing wild-type U2 (lane 2). We conclude that suppression by CUS1-54 of the growth defect caused by mutation of U2 G53A is mediated through a restoration of splicing efficiency in vivo.

A cold-sensitive defect in $\mathrm{U} 2$ function caused by the G53A mutation can be observed in splicing extracts $(\mathrm{Za}-$ vanelli and Ares 1991). The defect results in slow or inefficient conversion of commitment complexes to splic-

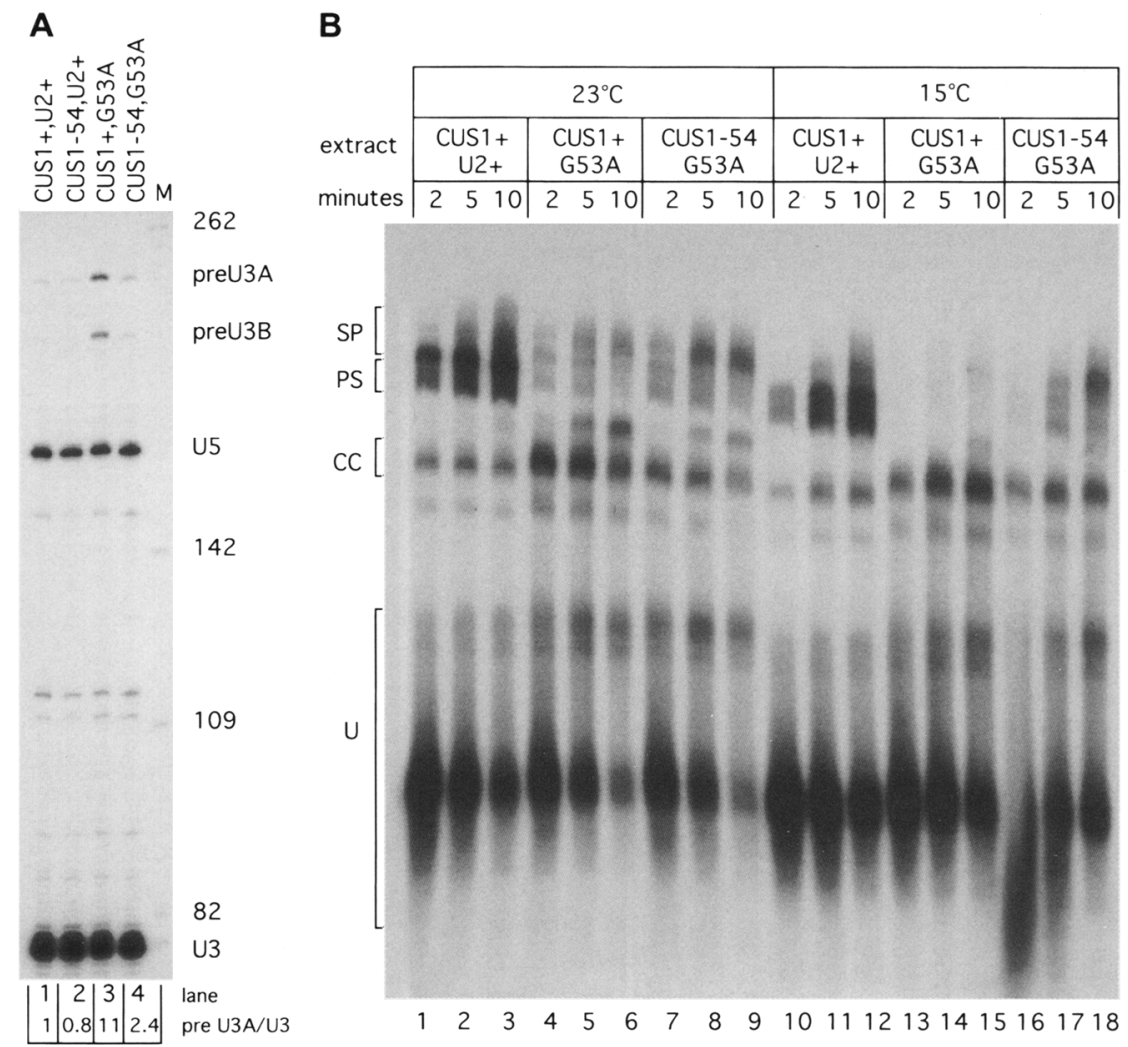


ing complexes containing the U2 snRNP (prespliceosomes and then subsequently spliceosomes), especially at low temperatures (Zavanelli and Ares 1991). To determine whether CUS1-54-mediated suppression occurs at the level of prespliceosome formation, we analyzed splicing extracts from different strains for the ability to form U2-containing splicing complexes at different temperatures in vitro, using native gel electrophoresis (Fig. 4B). Extracts from the wild-type strain form prespliceosomes efficiently after incubation at either $23^{\circ} \mathrm{C}$ or $15^{\circ} \mathrm{C}$ (lanes 1-3, 10-12). Extracts from strains carrying the U2-G53A mutation form prespliceosomes at a lower rate than wild type at $23^{\circ} \mathrm{C}$, and very poorly at $15^{\circ} \mathrm{C}$, with increased accumulation of commitment complexes (cf. lanes 4-6 with lanes 13-15). Extracts made from U2 G53A cells carrying the CUS1-54 plasmid form prespliceosomes at $23^{\circ} \mathrm{C}$ and are more efficient in prespliceosome formation at $15^{\circ} \mathrm{C}$, compared with extracts made from cells carrying the CUS $1^{+}$plasmid (cf. lanes 4-6 with 13-15 and lanes 7-9 with 16-18). The defect in prespliceosome formation caused by mutation of $\mathrm{U} 2$ G53A is suppressed in extracts containing CUS1-54 gene product, but not $\mathrm{CUS1}^{+}$gene product, indicating that the mechanism of CUS1-54 suppression in vitro is through enhancement of a spliceosome assembly step that leads to association of the U2 snRNP with commitment complexes.

The secondary structure of U2 G53A RNA is perturbed in the bulk of the U2 snRNP population in vivo, such that stem-loop IIa is not formed, and loop IIa is paired to a conserved region of complementarity downstream (Zavanelli and Ares 1991; Zavanelli et al. 1994). The growth and in vitro splicing defects of G53A and other mutations that destabilize stem $\mathrm{IIa}$, as well as many aspects of the RNA folding defect, can be suppressed by second mutations in U2 snRNA that disrupt the competing alternative structures that interfere with stem IIa formation (Zavanelli et al. 1994). We used in vivo RNA structure probing to assess the effect of CUS154 on the folding of the bulk U2 snRNA and observed no effect of the suppressor on the folding pattern of the U2 G53A RNA (data not shown). We conclude that CUS1-54 does not suppress U2 G53A cold-sensitive growth and prespliceosome formation defects by restoring the wild-type distribution of folded forms of $\mathrm{U} 2 \mathrm{sn}$ RNA in the cell.

\section{A discrete subset of U2 snRNA mutations is suppressed by CUS1-54}

Both the CUS1 protein and U2 stem-loop IIa are required for the stable association of U2 snRNP with premRNA (Fig. 3B; Zavanelli and Ares 1991), suggesting that suppression occurs when they act together at the same step in prespliceosome formation. However, a formal interpretation of the efficient dominant suppression by CUS1-54 is that the requirement for the stem-loop has been bypassed by the suppressor mutation. To address this possibility and to obtain clues to the mechanism by which CUS1-54 suppresses U2 G53A, we tested
CUS1-54 for suppression of other U2 mutations (Fig. 5). In addition to G53A, CUS1-54 suppresses the more severe phenotype of G53C. The pairing partner of G53 in the stem IIa is C62 (Ares and Igel 1990); the cold-sensitive phenotype of mutation $\mathrm{C} 62 \mathrm{U}$ is also suppressed. Mutation of C62 to G is not suppressed by CUS1-54 however, although this mutation can be suppressed by second U2 RNA mutations that change G53 to C, restoring the 53-62 base pair (Ares and Igel 1990), or G100 to A, destroying the conserved complementarity to loop IIa (Zavanelli et al. 1994). This result suggests that the mechanism of suppression by CUS1-54 is less efficient

A

\begin{tabular}{|l|c|c|c|c|c|c|}
\hline temperature & \multicolumn{2}{|c|}{$18^{\circ} \mathrm{C}$} & \multicolumn{2}{c|}{$26^{\circ} \mathrm{C}$} & \multicolumn{2}{c|}{$30^{\circ} \mathrm{C}$} \\
\hline U2 & CUS1 & CUS1-54 & CUS1 & CUS1-54 & CUS1 & CUS1-54 \\
\hline WT & ++++ & ++++ & ++++ & ++++ & ++++ & ++++ \\
G53A & - & +++ & ++ & ++++ & ++ & ++++ \\
G53C & - & ++ & - & ++ & - & + \\
C62U & - & +++ & + & ++++ & +++ & ++++ \\
C62G & - & - & - & - & - & - \\
A61 & ++ & ++ & ++ & ++ & ++ & ++ \\
BTL & - & - & - & - & - & - \\
tmA & - & - & - & - & - & - \\
tmA' & - & - & - & - & - & - \\
tmC' & +++ & +++ & ++++ & ++++ & ++++ & ++++ \\
U44A & - & - & + & + & + & + \\
U44G & - & - & - & - & - & - \\
U33 & ++++ & ++++ & +++ & +++ & ++ & +++ \\
C29 & + & + & - & - & - & - \\
\hline
\end{tabular}

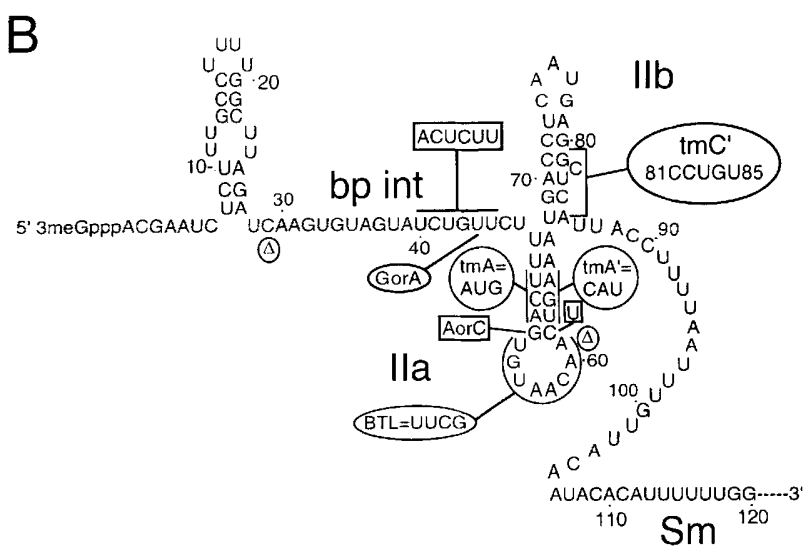

Figure 5. Allele-specific suppression of U2 mutants by CUS154. (A) CUS1 $^{+}$and CUS1-54 were tested for suppression of a series of $\mathrm{U} 2$ mutations with growth phenotypes. Growth was assayed on YEPD after 3 days at $26^{\circ} \mathrm{C}$ and $30^{\circ} \mathrm{C}$ and 5 days at $18^{\circ} \mathrm{C}$ and is indicated as follows: Wild-type growth $(++++)$; intermediate growth $(+++\mid$ to $|+|$; no growth $(-\mid)(B)$ Secondary structure model of the 5 ' end of U2 snRNA (Ares and Igel 1990) including the sequence of triple mutations in stem IIa and $\mathrm{IIb}$ and of the tetraloop used to replace loop IIa in the mutant BTL. Mutations suppressed by CUS1-54 are boxed; mutations that are not suppressed are circled. A collection of double and triple mutations in nucleotides $40-45$ are also suppressed by CUS1-54. A40C43 is included as a representative of these mutations (Yan and Ares 1996). 
than or qualitatively different from that of the intragenic suppressors.

CUS1-54 does not act to bypass the requirement for U2 snRNA or for stem-loop IIa in splicing, because it fails to suppress the lethal tetraloop replacement of loop $\mathrm{IIa}$ or the lethal triple mutations in stem IIa (Fig. 5; Ares and Igel 1990). This shows that suppression takes place by enhancing rather than replacing the function of this part of U2 snRNA. CUS1-54 does not simply enhance splicing at lower temperatures, because it fails to suppress other mild ( $\mathrm{tmC}^{\prime}$ ) or severe (U44A, U44G) coldsensitive mutations in U2 snRNA. CUS1-54 is particularly effective in the rescue of the stem IIa mutations but fails to significantly enhance the function of a single base deletion in loop IIa $(\mathrm{A} 61 \Delta)$ or either of two mutations upstream of the branchpoint interaction region

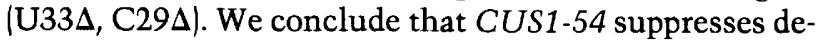
fects in U2 in large part through stem-loop IIa and does not simply bypass U2 function or generally enhance splicing at low temperature.

\section{Extra copies of CUS1 ${ }^{+}$but not CUS1-54 suppress the temperature-sensitive growth defects of prp5 and prpl1}

Synthetic lethal interactions have been observed between U2 snRNA and four proteins required for prespliceosome assembly (Ruby et al. 1993; Wells and Ares 1994). One of these is the DEAD-box protein PRP5 (Dalbadie-McFarland and Abelson 1990|, and the other three (PRP9, PRP11, and PRP21) comprise the yeast homolog of SF3a (Beggs 1993; Krämer 1993; Hodges and Beggs 1994; Newman 1994). To determine which if any of these proteins might interact with CUS1, we introduced CUS1 ${ }^{+}$or CUS1-54 on centromere plasmids into strains carrying different temperature-sensitive prp mutations. We found that extra copies of $C U S 1^{+}$partially suppress the temperature-sensitive growth defect of prp5-1 and prp11-1, but not prp4-1, prp9-1, or prp21-1 (Table 1). This result suggests that CUS1 interacts with the putative RNA helicase PRP5 as well as the yeast homolog of SF3a and is consistent with the interpretation that CUS1 functions with $U 2$ snRNA at the point of stable addition of U2 snRNP to the pre-mRNA. Surprisingly the CUS154 allele, which so effectively suppresses U2 mutations, fails to rescue any of the prp mutations. The diametric effects of CUS1-54 on suppression of U2 snRNA mutations and extra-copy rescue of prp5 and prp 11 indicate that the increased efficiency of interaction between $\mathrm{U} 2$ snRNA and CUSl comes at a cost to the interaction with PRP5 and yeast SF3a.

\section{CUS1 is a yeast homolog of the human U2 snRNP protein SAP 145}

The wild-type CUS1 protein is estimated to be $\sim 50 \mathrm{kD}$ in molecular mass, basic at neutral $\mathrm{pH}$ (estimated $\mathrm{pI}=8.7)$, and rich in charged residues $16.9 \%$ Asp, $9.4 \%$ Glu, $11.7 \%$ Lys, and $5.7 \% \mathrm{Arg}$. With the exception of a potential coiled-coil domain at the carboxyl terminus
Table 1. Suppression of prp5 and prp11 by extra copies of $\mathrm{CUS1}^{+}$

\begin{tabular}{|c|c|c|c|c|c|}
\hline \multirow[b]{2}{*}{ Strain } & \multirow[b]{2}{*}{ Plasmid } & \multicolumn{4}{|c|}{ Temperature } \\
\hline & & $26^{\circ} \mathrm{C}$ & $30^{\circ} \mathrm{C}$ & $34^{\circ} \mathrm{C}$ & $36^{\circ} \mathrm{C}$ \\
\hline \multirow[t]{3}{*}{ Wild type } & pRS316 & +++ & +++ & +++ & +++ \\
\hline & pRS316CUS1-54 & +++ & +++ & +++ & +++ \\
\hline & pRS316CUS $1^{+}$ & $+t+$ & +++ & +++ & +++ \\
\hline \multirow[t]{3}{*}{ prp4-1 } & pRS316 & +++ & - & - & - \\
\hline & pRS316CUS1-54 & $+t+$ & - & - & - \\
\hline & pRS316CUS1 ${ }^{+}$ & +++ & - & - & - \\
\hline \multirow[t]{3}{*}{ prp5-1 } & pRS316 & +++ & ++ & + & - \\
\hline & pRS316CUS1-54 & +++ & ++ & + & - \\
\hline & pRS316CUS $1^{+}$ & +++ & $+t$ & ++ & + \\
\hline \multirow[t]{3}{*}{ prp9-1 } & pRS316 & +++ & - & - & - \\
\hline & pRS316CUS1-54 & +++ & - & - & - \\
\hline & pRS316CUS1 ${ }^{+}$ & $++t$ & - & - & - \\
\hline \multirow[t]{3}{*}{ prp11-1 } & pRS316 & $+t+$ & ++ & - & - \\
\hline & pRS316CUS1.54 & +++ & ++ & - & - \\
\hline & pRS316CUS1 ${ }^{+}$ & +++ & +++ & + & - \\
\hline \multirow[t]{3}{*}{ prp21-1 } & pRS316 & +++ & - & - & - \\
\hline & pRS316CUS1-54 & $++t$ & - & - & - \\
\hline & pRS316CUS1 ${ }^{+}$ & +++ & - & - & - \\
\hline
\end{tabular}

$\mathrm{CUS1}^{+}$and CUS1-54 carried on centromere plasmids were tested for their ability to suppress the temperature-sensitive splicing mutants prp4, prp5, prp9, prp11; and prp21. Growth was assayed on YEPD after 3 days at $26^{\circ} \mathrm{C}, 30^{\circ} \mathrm{C}, 34^{\circ} \mathrm{C}$ or $36^{\circ} \mathrm{C}$ and is indicated as follows: $(+++)$ Wild type growth; $1++$ to $+)$ intermediate growth; $(-)$ no growth.

(Lupas et al. 1991), the protein lacks motifs that would link it convincingly to any of the known families of RNA-binding proteins. Furthermore, with the exception of the human, worm, and Arabidopsis sequences of unknown function discussed below, filtered BLAST searches fail to recognize homologous proteins of known function in the public data base. Recent efforts toward the cloning of human cDNAs encoding proteins associated with functional splicing complexes have led to the identification of a full-length cDNA encoding SAP 145, a U2 snRNP-associated protein (see Gozani et al., this issue). Alignment of the CUS1 protein sequence with the sequence of SAP 145 (Fig. 6) shows that the two genes share a $\sim 200$-amino-acid region of significant similarity (43\% identical, $65 \%$ similar), including the site of the suppressor substitution (Fig. 6). The region of significant similarity occupies the central parts of both proteins.

Comparison of the CUS1 and SAP 145 sequences shows that CUSl residue glutamate-181, which is changed to lysine in the CUS1-54 suppressor protein, unambiguously aligns with lysine- 487 in SAP 145. Thus, the human protein provides a phylogenetic example of the functionality of lysine at this position but offers no solid clues to the mechanism of suppression. Comparing the sequences of human $\mathrm{U} 2$ with those of the suppressible yeast U2 mutants does not suggest any RNA base whose recognition might be satisfied by the replacement of a potential hydrogen bond acceptor (E) with a donor (K). The suppressor substitution occurs in a residue sur- 
A

Cus $1-54 p$

CUS1p 127 RKTEKPSLSQLKSQVPYPQIIEWYDCDARYPGLLASIKCTKNVI PVPSHWQSKKEYLSGRSLLGK 191 $\begin{array}{lllllllll} & \mathrm{R}+ & + \\ \text { SAP145 } & 432 & \text { RRMNRFTVAELKOLVARPDVVEMHDVTAODPKLLVHLKATRNSVPVPRHWCFKRKYLOGKRGIEK } & 49\end{array}$ $\begin{array}{lcc}\text { CUS1p } & 192 \text { RPFELPDIIKKTNIEQMRSTLPQSGLDGQDEKSLKEASRARVQPKMGALDLDYKKLHDVFFKIGA } 256 \\ & \text { PFELPD IK+T I + MR L } \quad+\quad+++K++K \quad R+V \text { PKMG +D+DY+KLHD FFK } \\ \text { SAP145 } & 497 \text { PPFELPDFIKRTGIQEMREALQEK----EEQKTMKSKMREKVRPKMGKIDIDYQKLHDAFFKW-- } 555\end{array}$

CUS1P 257 NWKPDHLLCFGDVYYENRNLFEETNWKRMVDHKRPGRISQELRAIMNLPEG----
KP L LPPWCMKM 316 SAP145 556 QTKP-KLTIHGDLYYEGK-----EFETRLKEKKPGDLSDELRISLGMPVGPNAHKVPPPWLIAM 61

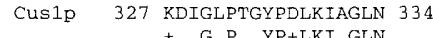

B

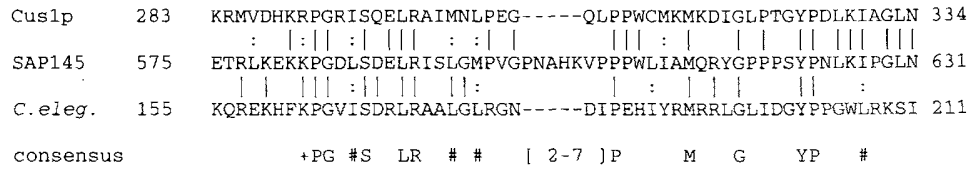

Figure 6. Homology between CUS1 and SAP 145 (A) Amino acid sequence alignment of CUSl and SAP 145. Sequences were aligned using results from the BLAST program (Altschul et al. 1990), as delivered (using the default settings) by the sequence search e-mail server at the National Library of Medicine. The ungapped segments of similarity were stitched together by visual inspection. Position of the suppressor substitution is indicated. $(B)$ A segment of homology between CUS1 and SAP 145 is present in a $C$. elegans protein. BLAST identified a C. elegans protein with homology to CUS1 and SAP 145 in a region of SAP 145 required for a proteinprotein interaction. The proteins were aligned using BLOCKMAKER (Henikoff et al. 1995) via the Baylor College of Medicine Search Launcher at http://dotimgen.bcm.tmc.edu:8088/search-launcher/

launcher.html. An expressed Arabidopsis homolog of CUS1/SAP 145 (GenBank H36362) used for the alignment is not shown. A consensus is listed below. Similar amino acids $(\mathrm{I}=\mathrm{L}=\mathrm{V}=\mathrm{M}, \mathrm{D}=\mathrm{E}, \mathrm{K}=\mathrm{R}$ ) are indicated by a colon. Hydrophobic (\#) and charged $1+\mid$ residues are indicated. rounded by conserved amino acids (H175, W176, K179, Y182, and L183). Structure predictions (Burkhard and Sander 1993) performed on each protein individually agree that the sequences surrounding residue 181 (or 487) are likely to be $\alpha$-helical. If this is the case, the side chains of the conserved amino acids would be positioned on one face of the helix, with residue 181 (487) on the opposite face. Even in the absence of other evidence for a specific protein secondary structure, the substitution of glutamate with lysine could be expected to increase the general affinity of the protein for RNA.

Sequences from two other organisms have significant homology to CUS1. An expressed Arabidopsis sequence (GenBank accession no. H36362) is very likely a SAP 145 homolog. A protein from Caenorhabditis elegans (SWISSPROT accession no. P34656) has a significant match to CUS1 and SAP 145 only in the carboxy-terminal segment of the homology between CUS1 and SAP 145 (Fig. 6B). The worm protein has a structural arrangement distinct from CUS1 or SAP 145 and contains a retroviral type Cys-Cys-His-Cys zinc finger motif amino-terminal to its region of similarity with CUS1 (data not shown). This suggests that the homology between CUS1 and SAP 145 consists of at least two parts, an amino-terminal part containing the suppressor mutation and found so far only in CUS1 and SAP 145, and a carboxy-terminal part which may be a modular protein structural element found in otherwise unrelated proteins. A protein-protein interaction between SAP 49 and SAP 145 has been mapped by the Far Western technique (Champion-Arnaud and Reed 1994; Gozani et al., this issue). Sequences in SAP 145 required for this interaction lie between residues 556 and 694 (Gozani et al., this issue), a segment that contains this structure. A second possibility is that the carboxy-terminal glutamate-rich segment is involved in the interaction with SAP 49 , as this element lies partly within the 556-694 region (Gozani et al., this issue). CUS1 also has a carboxy-terminal glutamate-rich region that scores very highly in a coiled-coil prediction program, designed to detect potential regions of protein-protein interaction (Lupas et al. 1991). The glutamate-rich region of SAP 145 does not score as highly in potential to form coiled coils. We did not attempt to align the glutamate-rich regions.

\section{A yeast homolog of SAP 49}

The similarity between CUS1 and SAP 145, and the strong protein-protein interaction between SAP 145 and SAP 49 (Champion-Arnaud and Reed 1994; see Gozani et al., this issue), predicted a yeast homolog of SAP 49. Recently, sequences from yeast (GenBank accession no. $\mathrm{X} 90565$ ) and $C$. elegans (SWISSPROT accession no. Q09442) have been released that match SAP 49 substantially more significantly than other RRM-containing proteins (Birney et al. 1993; Burd and Dreyfuss 1994) in BLAST searches. We aligned the sequences using CLUSTAL W (Fig. 7; Thompson et al. 1994). Over most of 160 of the first 200 amino acids, the yeast and human proteins are $40 \%-50 \%$ identical and $60 \%-70 \%$ similar. Patches of extreme similarity between the two proteins follow the RNP1 of the first RRM (62-71 yeast, 66-75 human), and RRM2 (residues $175-190$ in yeast; 169-184 in human). A carboxy-terminal proline-rich domain shared by the human and C. elegans proteins is absent in yeast. The proline-rich region is dispensable for the protein-protein interaction between SAP 49 and SAP 145 (Champion-Arnaud and Reed 1994). Based on this observation, we conclude that yeast encodes a protein homologous to SAP 49 . We call this yeast gene HSH49, for human SAP homolog 49. Experiments will be necessary 
Figure 7. A yeast homolog of human SAP 49. A filtered BLAST search was performed (both seg and xnu filters were used) using the human SAP 49 sequence. The yeast and C. elegans SAP 49 homologs were aligned using CLUSTAL W (Thompson et al. 1994), through the Baylor College of Medicine Search Launcher. The alignment was not adjusted, except that the proline-rich carboxy-terminal regions present in the human (to residue 424) and worm (to residue 379 ) proteins, but absent in yeast, have been omitted. Identical residues are in boldface type; residues that are similar or identical between the human and yeast protein have asterisks. The RNPl and RNP2 sequences of each of the two RRMs are underlined.

to determine whether and how this protein functions in collaboration with CUS1 during splicing.

\section{Discussion}

Using a genetic screen for suppressors of a mutation in U2 snRNA, we have identified a novel yeast gene CUS154 , which overcomes defects in U2 snRNA. The suppressor was selected to rescue a mutation in stem-loop IIa of U2 snRNA, an essential structure required for the stable binding of the U2 snRNP to pre-mRNA during spliceosome assembly (Ares and Igel 1990; Zavanelli and Ares 1991|. Rescue of U2 function by CUS1-54 occurs at the defective step (Fig. 4B) and does not bypass the requirement for U2 stem-loop IIa (Fig. 5). This suggests that the suppressor protein acts with stem-loop IIa to overcome the block to spliceosome assembly caused by mutation of the RNA. Consistent with this interpretation is evidence that the wild-type protein CUS1 is required for the addition of wild-type U2 snRNP to the assembling spliceosome (Fig. 3B). The wild-type CUS1 gene is essential and its expression is required for splicing in vivo (Fig. $3 A)$. Finally, CUS1 is homologous to SAP 145, a human U2-associated spliceosomal protein (Fig. 6; Gozani et al., this issue). The similarity between SAP 145 and CUS1 is strengthened by the identification of a yeast gene, HSH49, homologous to SAP 49 (Fig. 7), a human U2 protein that binds tightly to SAP 145 (Champion-Arnaud and Reed 1994).

\section{Conserved protein structure in the spliceosome}

Based on these similarities, we propose that yeast has an SF3b-like factor that includes CUS1 (and HSH49). The pattern of U2 mutations suppressed by CUS1-54 (Fig. 5), the role of U2 stem-loop IIa in splicing (Zavanelli and Ares 1991), and the structural parallels between CUS1 (and HSH49) and SAP 145 (and SAP 49) suggest that stem-loop IIa is a critical part of the SF3b binding site. Given the presence of conserved RRMs in HSH49 and SAP 49 (Fig. 7), as well as the conservation of stem-loop IIa RNA sequence (Ares and Igel 1990), it seems possible that one of the RRMs may bind stem-loop IIa directly or in conjunction with CUS1. The allele-specific pattern of synthetic lethality observed between U2 mutations and temperature-sensitive alleles of the genes encoding yeast SF3a (PRP9, PRP11, PRP21) and PRP5 supports this idea (Wells and Ares 1994) and suggests further that the binding detected between these proteins and U2 RNA (Abovich et al. 1990, 1994; Wells and Ares 1994) may be mediated through CUS1. Because mammalian SF3a depends on SF3b to bind U2 (Brosi et al. 1993a), the yeast SF3a homolog (composed of PRP9, PRP11, and PRP21) would be predicted to depend on the binding of CUS1 (and HSH49) for its association with yeast U2.

\section{What is the mechanism of suppression?}

How does mutation of CUS1 suppress U2 RNA defects? Second mutations elsewhere in U2 also suppress the defects of certain stem IIa mutants; these intragenic suppressors act to improve the stability of stem IIa relative to competing alternative U2 RNA structures (Zavanelli et al. 1994). Because of this parallel, and because the suppressor protein has little if any deleterious effect on growth or splicing, we propose that suppression occurs by increasing the efficiency with which the mutant $\mathrm{U} 2$ RNA is utilized in splicing. In this model the suppressor protein stimulates either the rate of refolding or recognition of U2 snRNA, relieving the block to splicing caused when the mutant U2 snRNP fails to be incorporated into spliceosomes rapidly enough to maintain cell growth (Zavanelli et al. 1994). Suppression by CUS1-54 could reflect direct binding to U2 snRNA, indirect binding to $\mathrm{U} 2$ through protein-protein interactions with $\mathrm{U} 2$ binding proteins, or stimulating the activity of the U2 snRNP by some other means. We favor the idea that CUS1 binds U2 snRNA, either directly or in conjunction with other proteins, and that the glutamate-to-lysine change caused by the CUS1-54 mutation improves binding of the protein to U2 RNA.

Mutations that increase the affinity of protein for nucleic acids are not unprecedented. Such mutations have been isolated in several well-studied nucleic acid-binding proteins and many alter negatively charged amino acids, rendering them neutral or positively charged. In glutaminyl-tRNA synthetase, mutations of Asp-235 (to Asn or Gly) cause mischarging by increasing the affinity of the enzyme for noncognate tRNAs without loss of affinity for the cognate tRNA (Perona et al. 1989; Sher- 
man et al. 1995|, thus reducing selectivity. The same forces may be at play in $\lambda$ repressor and catabolite activator protein, where several suppressors of operator mutations increase the binding of the respective protein to the target DNA at the expense of sequence discrimination (Nelson and Sauer 1985; Ebright et al. 1987; Benson et al. 1992). Similarly, the CUS1-54 suppressor protein may rescue $\mathrm{U} 2$ function by binding mutant $\mathrm{U} 2$ more tightly but may have lost some ability to discriminate between wild-type $U 2$ and other RNAs. Several proteins have been shown to increase the rate of RNA structural interconversion in vitro (Coetzee et al. 1994; Herschlag et al. 1994); it is also possible the suppressor enhances the rate of interconversion between the two differently folded forms of U2 snRNA.

A clue that CUS1-54 suppression of U2 defects bears as a cost a subtle loss of function can be found in the genetic interactions between CUS1, and PRP5 and PRP11. Extra copies of CUS1 ${ }^{+}$suppress the growth defects of PRP5 and PRP11 (Table 1), demonstrating functional interactions between yeast SF3a, PRP5, and CUS1, a putative SF3b component. Extra-copy rescue of the prp mutations is not supported by CUS1-54, implying that the glutamate-to-lysine substitution disrupts an interaction between CUS1 and SF3a and PRP5. A simple explanation for the diametric effects of the suppressor mutation is that there is a balance between the affinity of CUS1 for U2 snRNA on the one hand and the function of CUS1 with SF3a and PRP5 on the other. Although SF3a can bind U2 only in the presence of SF3b, and SF3b can bind U2 on its own (Brosi et al. 1993a), the two factors cochromatograph through several steps (Krämer and Utans 1991) and are probably associated in vivo. If SF3b alone binds U2 with higher affinity than SF3a $+b$, then the affinity of CUS1 for mutant U2 RNA could be increased simply by reducing the interaction between CUS1 and SF3a or PRP5. The suppressor protein would bind mutant U2 RNAs more tightly but would interact less avidly with SF3a and PRP5.

\section{CUS1/SAP 145 may interact with both U2 RNA and the pre-mRNA}

Our experiments in yeast are focused on the interaction between U2 RNA and CUS1; however, the human homolog of CUS1, SAP 145, is one of an intriguing set of proteins that can be photochemically cross-linked to the pre-mRNA branchpoint region within spliceosomes (see Gozani et al., this issue). Using labeled pre-mRNA and immunoprecipitation with the 12CA5 antibody, we tried but were unable to detect cross-linking of CUS1-tag to pre-mRNA in yeast splicing extracts. We can monitor the splicing of an intron with a UACUAAC to UACAAAC mutation by a U2 suppressor RNA with the compensatory G37U mutation (Parker et al. 1987); however, supplementation with CUS1-54 did not improve the efficiency of splicing of the mutant intron, with or without the branchpoint suppressor U2. Our attempts to coprecipitate U2 RNA with antibodies against the HA determinant in CUS1-tag suggest that either CUS1 is less tightly associated with $\mathrm{U} 2$ than the Sm D protein controls (Roy et al. 1995), or that the HA tag on CUS1 is much less accessible. These observations do not exclude the possibility that CUS1 is positioned a fixed distance from the pre-mRNA branchpoint in the yeast spliceosome. Instead, the pattern of suppression of U2 mutants and (Fig. 5) in vitro rescue of mutant U2 (Fig. 3B) by CUS1-54 argue for a role for CUS1/SAP 145 in mediating U2 RNA-protein interactions required to activate the U2 snRNP for spliceosome assembly. Taken together with the observations of Gozani et al. (this issue), a consistent hypothesis must include the establishment of early interactions between U2 RNA and CUS1/SAP 145 (Brosi et al. 1993a), and later interactions between premRNA near the branchpoint and CUS1/SAP 145 as part of the U2 snRNP (Staknis and Reed 1994; Gozani et al., this issue). Future experiments will determine how the different protein components of the splicing apparatus position both the substrate and the small nuclear RNAs at their proper places in the spliceosome.

\section{Materials and methods}

Genetic screen and cloning

Yeast strains were constructed and analyzed genetically by standard procedures (Sherman et al. 1986; Ausubel et al. 1987; Guthrie and Fink 1991). Yeast cells carrying a chromosomal U2 disruption and the cold-sensitive U2-G53A mutation on a LYS2 plasmid were treated with EMS to $90 \%$ lethality and plated on rich medium at $18^{\circ} \mathrm{C}$ as described previously (Zavanelli et al. 1994). Genomic DNA was partially digested with Sau3A, size selected on agarose gels and ligated with BamHI digested pRS315 (Sikorski and Hieter 1989), then electroporated into Escherichia coli according to Rose and Broach (1991). Library DNA isolated from $E$. coli was used to transform a yeast strain carrying the U2 disruption and a cold-sensitive U2 plasmid. $\mathrm{Leu}^{+}$, cold-resistant yeast colonies were picked, and DNA was isolated (Ausubel et al. 1987) and retransformed into E. coli. Individual library plasmids identified in this way were rescreened by retransformation into yeast; those that uniformly gave rise to cold-resistant transformants were analyzed by restriction mapping and subcloning. To sequence the $X$ hol fragment carrying CUS1-54, we cloned it in either orientation in pGEM7Zf + (Promega, Madison, WI) and constructed and sequenced a deletion plasmid series for each with exonuclease III (Erase-a-base, Promega, Madison, WI).

To confirm that the cloned locus was the same as the CUS154 gene we subcloned a SacI-XhoI fragment from downstream of the putative suppressor open reading frame /so that it would not contain the suppressor mutation) into the integrative LEU2 plasmid pRS305 (Sikorski and Hieter 1989). This plasmid was cut with BsmI at a unique site within the insert and used to transform a cold-sensitive strain, selecting for LEU2. Southern blotting showed that the LEU2 gene was integrated in the chromosome downstream of the putative suppressor locus. This strain was crossed to a leu $2^{-}$suppressor strain and tetrads were dissected to determine whether recombination could occur between the LEU2 marker and the suppressor mutation.

The CUS1-54 gene was used to regenerate the wild-type $\mathrm{CUS}^{+}$gene by oligonucleotide-directed mutagenesis (Kunkel 1985). The lethal deletion disruption allele of CUS1 was constructed by replacing a BsmI fragment spanning nucleotides 555-1659 and containing the suppressor mutation within the 
CUS1 open reading frame, with a BamHI fragment carrying the HIS3 gene. URA3- or TRP1-marked centromere plasmids carrying the wild-type or suppressor genes were constructed by ligation of the CUS1 or CUS1-54 XhoI-SacI fragment into pRS314 or pRS316 (Sikorski and Hieter 1989) cut with Xhol and SacI. Galactose-regulated tagged versions of CUS1 and CUS154 were constructed by amplifying the coding regions by PCR using primers designed to introduce NotI restriction sites at either end of the PCR product (lightning, 5'-ATATATATGCGGCCGCTATAGGCAGAGCATCAGA-3'; thunder, 5'-ATTATAATGCGGCCGCTTTCAATACAGTATATAGTTG- $\left.3^{\prime}\right)$. The products were ligated into the NotI site of pTAG, resulting in the in-frame addition of three alanine residues followed by the 9-amino-acid HA epitope (Kolodziej and Young 1991) and 6 histidines at the carboxyl terminus of CUS1 (pGCT) or CUS1-54 (PGEKT). The cloned PCR fragments were sequenced completely in each plasmid. Both fusion constructs complement the CUS1 knockout, and the tagged CUS1-54 construct suppresses the cold-sensitive U2 mutation. pTAG was constructed as a general utility vector for $G A L$-regulated expression of tagged proteins in yeast (G. Voeltz and $M$. Ares, unpubl.) by amplifying and cloning the fused HA-6HIS tag described by Peterson et al. (1994) into pYES1.2 (Invitrogen, San Diego, CA). The plasmids carrying the mutant alleles of $\mathrm{U} 2$ are as described (Ares and Igel 1990; Yan and Ares 1996).

\section{Yeast strains}

Strains carrying U2 disruption and U2 mutations on plasmids have been described (Ares and Igel 1990; Zavanelli et al. 1994). The temperature-sensitive prp strains SRY4-1b, SRY5-1b, SRY9-1c, SRY11-1c, and SRY21-1b have also been described (Ruby et al, 1993). Other strains are derived from IH1097 (MATa, leu2-3, 112, ura3-52, pep4-3, prb1, prc1). BJ81 is a derivative of $\mathrm{IH} 1097$ that carries a glucose-repressible U2 gene in the chromosome (Miraglia et al. 1991). HI227 carries the same markers as IH1097 but is also deleted for the HIS3 and LYS2 genes. SWY1 was constructed from $\mathrm{HI} 227$ by first transforming with a functional copy of the CUS1-54 gene on a URA3 plasmid (pGEKT) then replacing the chromosomal copy of CUS1 with the deletion-disruption allele described above. SWY2 carries a glucose-repressible CUS1 gene in the chromosome and was constructed from HI227 by replacing the chromosomal copy of CUS1 with an allele, GAL1:CUS1, in which the endogenous promoter has been replaced by the GAL1 promoter from pYES1.2 (Invitrogen). To integrate the GAL1:CUS1 construct, the yeast $2 \mu$ region and an internal fragment from CUS1 were removed from pGCT. The plasmid was then digested with KpnI, which cuts upstream of the CUS1 deletion and used to transform HI227. Transformants were selected on media containing galactose and lacking uracil. Integration at the CUS1 locus was confirmed by Southern blotting for both SWY1 and SWY2.

\section{RNA isolation and analysis}

To determine the efficiency of splicing in cells depleted of CUS1, strains SWY2 (carrying the glucose-repressible chromosomal CUS1 gene) or an isogenic control (HI227) were grown to $\mathrm{OD}_{600}=2$ at $30^{\circ} \mathrm{C}$ in YPGal and diluted into $50 \mathrm{ml}$ of either YPGal or YEPD to a final $O_{600}=0.05$. After $7 \mathrm{hr}$ of growth, cells reached $\mathrm{OD}_{600}=0.4-0.8$, and were harvested. To determine whether CUS1-54 suppresses the cold-sensitive splicing defect of U2 G53A, derivatives of BJ81 were grown to $\mathrm{OD}_{600}=0.5$ at $30^{\circ} \mathrm{C}$ and shifted to $18^{\circ} \mathrm{C}$. Cells were harvested after $2 \mathrm{hr}$ of growth at $18^{\circ} \mathrm{C}$. RNA was isolated as described previously (Ares and Igel 1990) and resuspended in DEPCtreated water at a nucleic acid concentration of $1 \mathrm{mg} / \mathrm{ml}$. Primer extensions were performed on $5 \mu \mathrm{g}$ of total RNA using ${ }^{32} \mathrm{P}$-end-labeled oligonucleotides as described previously (Ares and Igel 1990). Annealing was carried out at $50^{\circ} \mathrm{C}$. The sequences of the oligonucleotides used for primer extension are as follows: U3A + B, 5'-CCAAGTTGGATTCAGTGGCTC-3', scR1-108，5'GGCGTGCAATCCGTGTCT3'; YU5，5'AAGTTCCAAAAAATATGGCAAGC3'.

\section{In vitro splicing}

Whole-cell extracts were prepared as described by Lin et al. (1985) from derivatives of BJ81 grown in YEPD and were assayed as described by McPheeters et al. (1989). Actin pre-mRNA substrate was synthesized in vitro essentially as described by Milligan and Uhlenbeck (1989) and gel purified on a 6\% denaturing acrylamide gel. The template for substrate synthesis is a wildtype actin intron and is described by Zavanelli and Ares (1991). CUS1-depleted extracts were made by growing a preculture of SWY2 to $O D_{600}=4.0$ in YPGal and diluting to $\mathrm{OD}_{600}=0.03$ in 1 liter of YEPD; cells were harvested after $14 \mathrm{hr}$ at $30^{\circ} \mathrm{C}$.

To assay for cold-sensitive complex formation, $25 \mu \mathrm{l}$ splicing reactions were assembled on ice and incubated at the indicated temperatures. At each time point $5 \mu \mathrm{l}$ aliquots were removed and mixed with an equal volume of ice-cold $R^{*}$ buffer $150 \mathrm{~mm}$ HEPES at $\mathrm{pH} 7.6,2 \mathrm{~mm} \mathrm{MgOAc}$ ) with $2 \mathrm{mg} / \mathrm{ml}$ of total yeast RNA, and incubated for $10 \mathrm{~min}$ on ice, then $2.5 \mu \mathrm{l}$ of $5 \times$ loading dye $(2.5 \times \mathrm{TBE}, 50 \%$ glycerol, bromophenol blue) was added, and the reactions were loaded on a native gel as described (Séraphin and Rosbash 1989, 1991). Gels were run at $100 \mathrm{~V}$ for $20 \mathrm{hrs}$ at $4^{\circ} \mathrm{C}$.

CUS1-tag protein fractions used to reconstitute CUS1-depleted extracts were made as follows. Yeast strain 334 (Hovland et al. 1989) carrying either the GAL1:CUS1-tag construct (pGCT) or the vector alone (pTAG) were grown to $\mathrm{OD}_{600}=4$ in 1 liter of YEPD to $\mathrm{OD}_{600}=2$, and $50 \mathrm{ml}$ of $40 \%$ galactose was added to induce the galactose-regulated promoter. After $3 \mathrm{hr}$, cells were pelleted, washed once with sorbitol buffer ( $1 \mathrm{M}$ sorbitol, $10 \mathrm{mM} \mathrm{MgCl}_{2}, 50 \mathrm{~mm}$ Tris- $\mathrm{HCl}$ at $\mathrm{pH}=8.0$ ), resuspended in buffer MD (10 mM HEPES at pH 7.9, 20\% glycerol, $200 \mathrm{mM} \mathrm{KCl}$, $0.5 \mathrm{mM}$ PMSF, $0.5 \mu \mathrm{g} / \mathrm{ml}$ of leupeptin, $0.75 \mu \mathrm{g} / \mathrm{ml}$ of pepstatin), and broken by vortexing with glass beads $\left(3 \times 30 \mathrm{sec}\right.$ at $\left.4^{\circ} \mathrm{C}\right)$, with $2 \mathrm{~min}$ between vortexing. The lysates were allowed to settle for $5 \mathrm{~min}$ on ice, and the supernatant was removed to an Oakridge tube and centrifuged at $37 \mathrm{~K}$ for $1 \mathrm{hr}$. The clear supernatant was then incubated in batch with $750 \mu l$ of NiNTA-agarose (QIAGEN, Chatsworth, CA, for $2-3 \mathrm{hr}$ at $4^{\circ} \mathrm{C}$ with slow rotation, washed four times with buffer MD with $10 \mathrm{~mm}$ imidazole, (pH 7.9). Bound protein was eluted with $250 \mu \mathrm{l}$ of buffer MD with $250 \mathrm{~mm}$ imidazole, (pH 7.9), on ice for $20 \mathrm{~min}$ with occasional mixing and concentrated fivefold with a Microcon 30 microconcentrator (Amicon, Beverly, MA). Western blot analysis using polyclonal antibody $12 \mathrm{CA} 5$ (BAbCO, Emeryville, CA) was used to assay for the presence of the tagged protein.

Reconstitution reactions were performed by mixing $1 \mu \mathrm{l}$ of eluent $(1 \mathrm{mg} / \mathrm{ml})$ with $1 \mu \mathrm{l}$ of $20 \mathrm{~mm}$ ATP, $2 \mu \mathrm{l}$ of $5 \times$ splicing salts, $1 \mu \mathrm{l}$ of $2 \mathrm{mM} \mathrm{E}$. coli rRNA, and $4 \mu \mathrm{l}$ of splicing extract, and incubating at $23^{\circ} \mathrm{C}$ for $5 \mathrm{~min}$. Then $1 \mu \mathrm{l}$ of actin pre-mRNA substrate (5-10 fmoles) was added, and the reactions were incubated for an additional $20 \mathrm{~min}$. The reactions were quenched as described above by adding $10 \mu l$ of ice cold $R^{*}$, incubating for $10 \mathrm{~min}$. on ice, followed by the addition of $5 \mu \mathrm{l}$ of $5 \times$ loading dye. Reactions were run on a native gel for $20 \mathrm{hrs}$ as described above. 


\section{Acknowledgments}

This work was supported by grant GM40478 from the National Institute of General Medical Sciences and a Research Career Development Award to M.A. S.E.W., M.H., and J.W. were supported on a training grant from the University of California Biotechnology Committee. PhosphorImager analysis was supported by grant BIR-9318111 from the National Science Foundation. We thank $R$. Reed for sharing results prior to publication and for comments on the manuscript. We thank John Tamkun for expert instruction and assistance in computer generation of figures and Ken Howe and Kate Lieberman for constructive comments on the manuscript.

The publication costs of this article were defrayed in part by payment of page charges. This article must therefore be hereby marked "advertisement" in accordance with 18 USC section 1734 solely to indicate this fact.

\section{References}

Abovich, N., P. Legrain, and M. Rosbash. 1990. The yeast PRP6 gene encodes a U4/U6 small nuclear ribonucleoprotein particle (snRNP) protein, and the $P R P 9$ gene encodes a protein required for U2 snRNP binding. Mol. Cell Biol. 10: 64176425.

Abovich, N., X.C. Liao, and M. Rosbash. 1994. The yeast MUD2 protein: An interaction with PRP11 defines a bridge between commitment complexes and U2 snRNP addition. Genes \& Dev. 8: 843-854.

Altschul, S., W. Gish, W. Miller, E. Myers, and D. Lipman. 1990. Basic local alignment search tool. J. Mol. Biol. 215: 403-410.

Arenas, J. and J. Abelson. 1993. The Saccharomyces cerevisiae PRP21 gene product is required for pre-spliceosome assembly. Proc. Natl. Acad. Sci. 90: 6771-6775.

Ares, M. Jr. and A.H. Igel. 1990. Lethal and temperature sensitive mutations and their suppressors identify an essential structural element in U2 small nuclear RNA. Genes \& Dev. 4: $2132-2145$

Ares, M. Jr. and B. Weiser. 1995. Rearrangement of snRNA structure during assembly and function of the spliceosome. Prog. Nucleic Acids Res. Mol. Biol. 50: 131-159.

Ausubel, F.M., R. Brent, R.E. Kingston, D.D. Moore, J.G. Seidman, J.A. Smith, and K. Struhl, eds. 1987. Current protocols in molecular biology. Greene/John Wiley \& Sons, New York.

Beggs, J.D. 1993. Yeast protein splicing factors involved in nuclear pre-mRNA splicing. Mol. Biol. Rep. 18: 99-103.

Behrens, S.-E., F. Galisson, P. Legrain, and R. Lührmann. 1993a. Evidence that the $60-\mathrm{kDa}$ protein of $17 \mathrm{~S}$ U2 small nuclear ribonucleoprotein is immunologically and functionally related to the yeast PRP9 splicing factor and is required for the efficient formation of prespliceosomes. Proc. Natl. Acad. Sci. 90: 8229-8233.

Behrens, S.-E., K. Tyc, B. Kastner, J. Reichelt, and R. Lührmann. 1993b. Small nuclear ribonucleoprotein (RNP) U2 contains numerous additional proteins and has a bipartite RNP structure under splicing conditions. Mol. Cell. Biol. 13: 307-319.

Bennett, M. and R. Reed. 1993. Correspondence between a mammalian spliceosome component and an essential yeast splicing factor. Science 262: 105-108.

Bennett, M., S. Michaud, J. Kingston, and R. Reed. 1992. Protein components specifically associated with prespliceosome and spliceosome complexes. Genes \& Dev. 6: 1986-2000.

Benson, N., C. Adams, and P. Youderian. 1992. Mutant $\lambda$ repressors with increased operator affinities reveal new, specific protein-DNA contacts. Genetics 130: 17-26.
Birney, E., S. Kumar, and A.R. Krainer. 1993. Analysis of the RNA-recognition motif and RS and RGG domains: Conservation in metazoan pre-mRNA splicing factors. Nucleic Acids Res. 21: 5803-5816.

Brosi, R., K. Gröning, S.-E. Behrens, R. Lührmann, and A. Krämer. 1993a. Interaction of mammalian splicing factor SF3a with U2 snRNP and relation of its $60-\mathrm{kD}$ subunit to yeast PRP9. Science 262: 102-105.

Brosi, R., H.-P. Hauri, and A. Krämer. 1993b. Separation of splicing factor SF3 into two components and purification of SF3a activity. J. Biol. Chem. 268: 17640-17646.

Burd, C.G. and G. Dreyfuss. 1994. Conserved structures and diversity of functions of RNA-binding proteins. Science 265::615-621.

Burkhard, R. and C. Sander. 1993. Prediction of protein secondary structure at better than $70 \%$ accuracy. I. Mol. Biol. 232: 584-599.

Champion-Arnaud, P. and R. Reed. 1994. The prespliceosome components SAP 49 and SAP 145 interact in a complex implicated in tethering U2 snRNP to the branch site. Genes \& Dev. 8: 1974-1983.

Chapon, C. and P. Legrain. 1992. A novel gene, spp91-1, suppresses the splicing defect and the pre-messenger-RNA nuclear export in the prp9-1 mutant. EMBO J. 11: 3279-3288.

Chiara, M.D., P. Champion-Arnaud, M. Buvoli, B. Nadal-Ginard, and R. Reed. 1994. Specific protein-protein interactions between the essential mammalian spliceosome-associated proteins SAP 61 and SAP 114. 1994. Proc. Natl. Acad. Sci. 91: 6403-6407.

Coetzee, T., D. Herschlag, and M. Belfort. 1994. Escherichia coli proteins, including ribosomal protein $\mathrm{S12}$, facilitate in vitro splicing of phage T4 introns by acting as RNA chaperones. Genes \& Dev. 8: 1575-1588.

Dalbadie-Mcfarland, G. and J. Abelson. 1990. PRP5: A helicuselike protein required for mRNA splicing in yeast. Proc. Natl. Acad. Sci. 87: 4236-4240.

Ebright, R.H., A. Kolb, H. Buc, T.A. Kunkel, and J.S. Krakow. 1987. Role of glutamic acid-181 in DNA-sequence recognition by the catabolite gene activator protein (CAP) of Escherichia coli: Altered DNA-sequence-recognition properties of [Val $\left.{ }^{181}\right] \mathrm{CAP}$ and [Leu $\left.{ }^{181}\right] \mathrm{CAP}$. Proc. Natl. Acad. Sci. 84: 6083-6087.

Felici, F., G. Cesareni, and J.M.X. Hughes. 1989. The most abundant small cytoplasmic RNA of Saccharomyces cerevisiae has an important function required for normal cell growth. Mol. Cell. Biol. 9: 3260-3268.

Gozani, O., R. Feld, and R. Reed. 1995. Sequence independent protein premRNA interactions upstream of the branch site are required for spliceosome assembly. Genes $\& \mathrm{Dev}$. (this issuel.

Guthrie, C. and G.R. Fink. 1991. Guide to yeast genetics and molecular biology. Academic Press, San Diego, CA.

Henikoff, S., J.G. Henikoff, W.J. Alford, and S. Peitrokovski. 1995. Automated construction and graphical presentation of protein blocks from unaligned sequences. Gene-COMBIS, Gene 163: GC17-26.

Herschlag, D., M. Khosla, Z. Tsuchihashi, and R.L. Karpel. 1994. An RNA chaperone activity of non-specific RNA binding proteins in hammerhead ribozyme catalysis. EMBO $J$. 13: 2913-2924.

Hochuli, E. 1990. Purification of recombinant proteins with metal chelate adsorbent. 1990. Genet. Eng. 12: 87-98.

Hodges, P.E. and J.D. Beggs. 1994. U2 fulfills a commitment. Curr. Biol. 4: 264-267.

Hovland, P., J. Flick, M. Johnston, and R.A. Scalfani. 1989. Galactose as a gratuitous inducer of GAL gene expression in 
yeasts growing on glucose. Gene 83: 57-64.

Kolodziej, P.A. and Young, R.A. 1991. Epitope tagging and protein surveillance. Methods Enzymol. 194: 508-519.

Krämer, A. 1993. Mammalian protein factors involved in nuclear pre-mRNA splicing. Mol. Biol. Rep. 18: 93-98.

Krämer, A. and U. Utans. 1991. Three protein factors (SF1, SF3 and $U 2 \mathrm{AF}$ ) function in pre-splicing complex formation in addition to snRNPs. EMBO J. 10: 1503-1509.

Krämer, A., P. Legrain, F. Mulhauser, K. Gröning, R. Brosi, and G. Bilbe. 1994. Splicing factor SF3a60 is the mammalian homologue of PRP9 of S. cerevisiae: The conserved zinc finger-like motif is functionally exchangeable in vivo. Nucleic Acids Res. 22: 5223-5228.

Krämer, A., F. Mulhauser, C. Wersig, K. Gröning, and G. Bilbe. 1995. Mammalian splicing factor SF3a 120 represents a new member of the SURP family of proteins and is homologous to the essential splicing factor PRP2lp of $S$. cerevisiae RNA. 1: 260-272.

Kunkel, T. 1985. Rapid and efficient site-specific mutagenesis without phenotypic selection. Proc. Natl. Acad. Sci. 82: $488-492$.

Legrain, P. and C. Chapon. 1993. Interaction between PRP11 and SPP91 yeast splicing factors and characterization of a PRP9-PRP11-SPP91 complex. Science 262: 108-110.

Legrain, P., C. Chapon, and F. Galisson. 1993. Interactions between PRP9 and SPP91 splicing factors identify a protein complex required in prespliceosome assembly. Genes \& Dev. 7: 1390-1399.

Lin, R.-J., A.J. Newman, S.-C. Cheng, and J. Abelson. 1985. Yeast mRNA splicing in vitro. J. Biol. Chem. 260: 1478014792.

Lin. R.-J., A.J. Lustig, and J. Abelson. 1987. Splicing of yeast nuclear pre-mRNA in vitro requires a functional $40 \mathrm{~S}$ spliceosome and several extrinsic factors. Genes \& Dev. 1: 7-18.

Lupas A., M. Van Dyke, and J. Stock. 1991. Predicting coiled coils from protein sequence. Science 252: 1162-1164.

McPheeters, D.S., P. Fabrizio, and J. Abelson. 1989. In vitro reconstitution of functional yeast U2 snRNPs. Genes \& Dev. 3: 2124-2136.

Milligan, J. and O. Uhlenbeck. 1989. Synthesis of small RNAs using T7 RNA polymerase. Methods Enzymol. 180: 51-62.

Miraglia, L., S. Seiwert, A. Igel, and M. Ares. 1991. Limited functional equivalence of phylogenetic variation in small nuclear RNA: Yeast U2 RNA with altered branchpoint complementarity inhibits splicing and produces a dominant lethal phenotype. Proc. Natl. Acad. Sci. 88: 7061-7065.

Moore, M.J., C.C. Query, and P.A. Sharp. Splicing of Precursors to mRNA by the Spliceosome. 1993. In The RNA world led R. Gesteland and I. Atkins), pp. 303-357. Cold Spring Harbor Laboratory Press, Cold Spring Harbor, NY.

Nelson, H.C.M. and R.T. Sauer. 1985. Lambda repressor mutations that increase the affinity and specificity of operator binding. Cell 42: 549-558.

Newman, A.J. 1994. Pre-mRNA splicing. Curr. Opin. Genet. Dev. 4: 298-304.

Nilsen, T.W. 1994. RNA-RNA interactions in the spliceosome: Unraveling the ties that bind. Cell 78: $1-4$.

Parker, R., P.G. Siliciano, and C. Guthrie. 1987. Recognition of the TACTAAC box during $\mathrm{mRNA}$ splicing in yeast involves base pairing to the U2-like snRNA. Cell 49: 229-239.

Perona, J.J., R.N. Swanson, M.A. Rould, T.A. Steitz, and D. Söll. 1989. Structural basis for misaminoacylation by mutant $E$. coli glutaminly-tRNA synthetase enzymes. Science 246: $1152-1154$.

Peterson, C.L., A. Dingwall, and M.P. Scott. 1994. Five SWI/ SNF gene products are components of a large multisubunit complex required for transcriptional enhancement. Proc. Natl. Acad. Sci. 91: 2905-2908.

Rose, M.D. and J.R. Broach. 1991. Cloning genes by complementation in yeast. Methods Enzymol. 194: 195-230.

Rothstein, R. 1991. Targeting, disruption, replacement, and allele rescue: Integrative DNA transformation in yeast. Meth ods Enzymol. 194: 281-301.

Roy, J., B. Zheng, B.C. Rymond, and J.L. Woolford Jr. 1995. Structurally related but functionally distinct yeast Sm D core small nuclear ribonucleoprotein particle proteins. Mol. Cell Biol. 15: 445-455.

Ruby, S., T.-H. Chang, and J. Abelson. 1993. Four yeast spliceosomal proteins (PRP5, PRP9, PRP11, and PRP21) interact to promote U2 snRNP binding to pre-mRNA. Genes \& Dev. 7: 1909-1925.

Séraphin, B. and M. Rosbash. 1989. Identification of functional U1 snRNA-pre-mRNA complexes committed to spliceosome assembly and splicing. Cell 59: 349-358.

. 1991. The yeast branchpoint sequence is not required for the formation of a stable U1 snRNA-pre-mRNA complex and is recognized in the absence of U2 snRNA. EMBO $/$. 10: $1209-1216$

Sherman, F. and P. Wakem. 1991. Mapping yeast genes. Methods Enzymol. 194: 38-57.

Sherman, F., G. Fink, and J. Hicks. 1986. Methods in yeast genetics. Cold Spring Harbor Laboratory, Cold Spring Harbor, NY.

Sherman, J.M., M.J. Rogers, and D. Söll. 1995. Recognition in the glutamine $t R N A$ system: From structure to function, in $t$ RNA. In Structure, biosynthesis, and function (ed. D. Söll and Uttam RajBhandryl, pp. 395-409. American Society for Microbiology, Washington D.C.

Sikorski, R.S. and P. Hieter. 1989. A system of shuttle vectors and yeast host strains designed for efficient manipulation of DNA in Saccharomyces cerevisiae. Genetics 122: 19-27.

Staknis, D. and R. Reed. 1994. Direct interactions between premRNA and six U2 small nuclear ribonucleoproteins during spliceosome assembly. Mol. Cell. Biol. 14: 2994-3005.

Thompson, J.D, D.G. Higgins, and T. J. Gibson. 1994 CLUSTAL W: Improving the sensitivity of multiple sequence alignments through sequence weighting, positionspecific gap penalties and weight matrix choice. Nucleic Acids Res. 22: 4673-4680.

Wells, S.E. and M. Ares, Jr. 1994. Interactions between highly conserved U2 small nuclear RNA structures and Prp5p, Prp9p, PRP11 and Prp2lp proteins are required to ensure integrity of the U2 small nuclear ribonucleoprotein in Saccharomyces cerevisiae. Mol. Cell. Biol. 14: 6337-6349.

Wu, J. and J.L. Manley. 1989. Mammalian pre-mRNA branch site selection by U2 snRNP involves base pairing. Genes \& Dev. 3: 1553-1561.

Yan, D. and M. Ares Ir. 1996. Invariant U2 RNA sequences bordering the branchpoint recognition region are essential for interaction with yeast SF3 and SF3b subunits. Mol. Cell. Biol. 16: (in press).

Zavanelli, M.I. and M. Ares Jr. 1991. Efficient association of U2 snRNPs with pre-mRNA requires an essential U2 RNA structural element. Genes \& Dev. 5: 2521-2533.

Zavanelli, M.I., J.S. Britton, A.H. Igel, and M. Ares Jr. 1994 Mutations in an essential U2 small nuclear RNA structure cause cold-sensitive U2 small nuclear ribonucleoprotein function by favoring competing alternative U2 RNA structures. Mol. Cell. Biol. 14: 1689-1697.

Zhuang, Y. and A.M. Weiner. 1989. A compensatory base change in human U2 snRNA can suppress a branch site mutation. Genes \& Dev. 3: 1545-1552. 


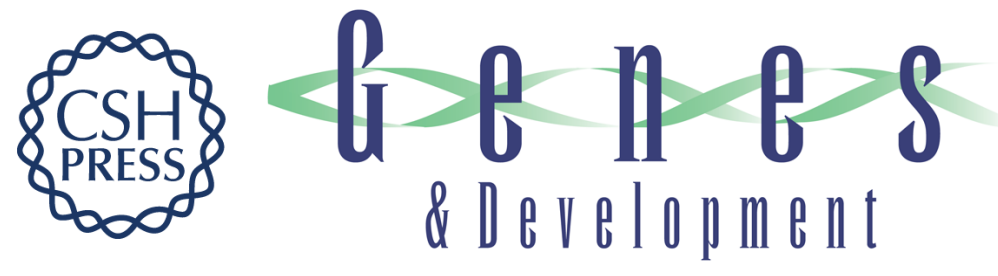

\section{CUS1, a suppressor of cold-sensitive U2 snRNA mutations, is a novel yeast splicing factor homologous to human SAP 145.}

S E Wells, M Neville, M Haynes, et al.

Genes Dev. 1996, 10:

Access the most recent version at doi:10.1101/gad.10.2.220

References

License

Email Alerting

Service
This article cites 64 articles, 37 of which can be accessed free at: http://genesdev.cshlp.org/content/10/2/220.full.html\#ref-list-1

Receive free email alerts when new articles cite this article - sign up in the box at the top right corner of the article or click here.

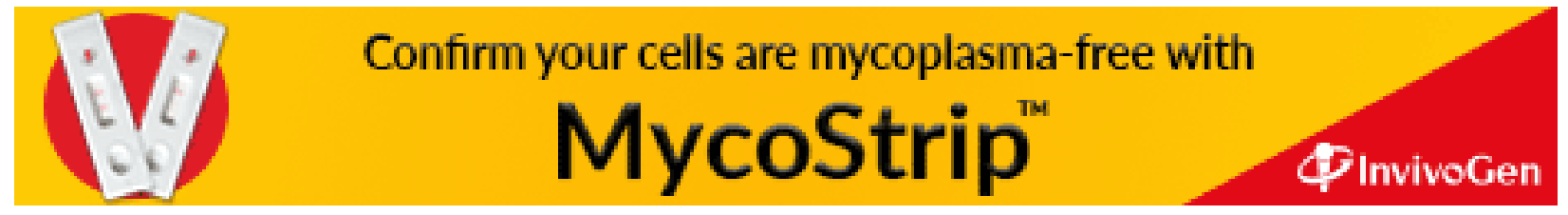

